\title{
ESP VIRTUAL LEARNING MEDIA EVALUATION: A CASE OF ENGLISH FOR RESTAURANT WORKERS
}

\author{
Muhamad Nova \\ Institut Pariwisata dan Bisnis Internasional, Denpasar \\ mnov493@stpbi.ac.id
}

\begin{abstract}
The development of technology recently demands a shift in the English language teaching and learning process, and to support the independence of language learning, virtual learning becomes an option to bridge the need for technology integration and open-learning access from the internet. This research aimed at finding out the learning media evaluation for teaching English for restaurant workers through virtual learning, i.e. video, podcast, virtual simulation, and PowerPoint presentations. This research was carried out by conducting qualitative research. The data were collected using questionnaires to 57 students in a vocational education institution and an interview with several selected students to clarify and to confirm their unclear statements on the questionnaire. The data were then analyzed by calculating the frequency of students' responses and classifying the responses toward the learning media application in virtual learning. As a result, it was found that video becomes the most preferable learning media and PowerPoint Presentations become the least preferable learning media in virtual learning for English for restaurant workers. The results also indicated that the mode of the video was more attractive and understandable since it could combine both audio and visual aids in the learning process, and support the students' skill enhancement. Meanwhile, the single-mode PowerPoint Presentations were less attractive for the students and led them to boredom. Henceforth, the English teachers and lecturers who teach English for Specific Purposes are suggested to provide more video simulations on virtual learning platform to support the engagement of the teaching and learning activities.
\end{abstract}

Keywords: English for restaurant workers, English for specific purpose, Learning media, Virtual learning

\section{A. INTRODUCTION}

he development of technology recently demands a shift in the teaching and learning process. As what the recent trends on education shown up, in 4.0 Industry, the

L teaching and learning processes need to integrate technology and the internet as the basic requirements to support the independence of the students in accessing the source of knowledge and expanding their personal abilities, professionalism, and connection (Kumar et al., 2020). The integration of technology is believed to benefit the teaching and learning process (Ilmi et al., 2020) and the existence of the internet could keep the connection among the classroom and speed up the exchange of information (Mustafa Kamal et al., 2019; Susilo, 2020) during the process of learning.

Profoundly, the integration of technology has been proven to affect the ambiance of language teaching and learning activities. By providing technology-based learning media, it builds a student-friendly learning environment which promotes a more enjoyable learning atmosphere and provides less pressure in the learning process (BaØöz, 2016; Meshkat \& 
Mohammadpoor, 2015). The technology integration can also foster students' interest, enthusiasm, and motivation in learning (Alresheed et al., 2015) who actively taking a part in the process of learning (Isisag, 2012). Moreover, technology integration can also support student's autonomy in having their own learning style preference in the process of learning (Ezza \& Bakry, 2015; Kofar, 2016). Therefore, technology integration is served as an aid to support language teaching and learning in the classroom.

On the other hand, the availability of the internet can also support the process of language teaching and learning. To support the independence of language learning, virtual learning becomes a medium to bridge the need for technology integration and open-learning access from the internet. In virtual learning, the activities are held using technologies and delivered through the internet, such as online learning resources, online multimedia, or live web conferencing (Al-Obaydi, 2019; Lopukhova \& Makeeva, 2017). It provides time flexibility in conducting teaching and learning activities, including material access, discussion, assessment, and evaluation (Al-Obaydi, 2019; Jamal \& Aldaifallah, 2020). Moreover, the platform served in virtual learning can also enable interaction and communication between teacher and students to discuss the learning material and earn learning feedback (Kristóf \& Tóth, 2020; Morales-Salas et al., 2020). Therefore, virtual learning can enable the teaching and learning process on any occasion.

However, the challenge occurs in providing virtual learning for vocational education. The focus of vocational learning does not only provide theory but also gives the authentic experience on applying what they learn into praxis. In vocational learning, English is taught as English for Specific Purpose, which focuses on practical use rather than theory-basis learning. The students are demanded to have more praxis on the language skills and focus on certain specialty and scope (Bekteshi \& Xhaferi, 2020; Salmani-nodoushan, 2020), such as English for restaurant workers, English for hoteliers, etc. In previous observation in one vocational college, the researcher observed that several English lecturers have successfully utilized several types of technology-based media in their virtual learning, including video, podcast, virtual simulation through videoconferencing, and PowerPoint Presentations. Although, the attitudes from the students toward the learning media were vary. Therefore, the evaluation of learning media which is proper to support the students' language learning and language praxis in virtual learning is necessary.

Taking into consideration of the virtual learning media, this research aimed at evaluating the proper learning media for teaching ESP through virtual learning. Precisely, this study focused on evaluating the virtual learning media, i.e. video, podcast, virtual simulation through 
Volume 7, Number 01, June 2021

videoconferencing, and PowerPoint Presentations, provided for teaching English for restaurant workers to support students' language learning and language praxis.

\section{B. REVIEW OF LITERATURE}

\section{Virtual Learning}

The trend of virtual learning involvement is rapidly increasing. The recent development in education pushes educators and also stakeholders to shift the paradigm of teaching and learning activities from traditional teaching to virtual learning. Virtual learning is a process of learning which integrates technology by utilizing computer-based tools and online resources in learning (Al-Obaydi, 2019). During the process of virtual learning, the teacher could provide a series of online learning multimedia to support the learning processes and interactive online learning platforms to bridge the interaction between the teacher and the students (MoralesSalas et al., 2020). With various media provided, virtual learning could offer a pleasant experience for the students and encourage them to explore new elements and knowledge in the learning process (de Almeida Ferreira et al., 2020; Morales-Salas et al., 2020). Specifically, they earn the flexibility in accessing the open online learning source which can provide them the autonomy in learning (Al-Obaydi, 2019; Jamal \& Aldaifallah, 2020). With the feasibility of learning source access, it gives independence for students in managing their own learning progress (Kumar et al., 2020). Therefore, the existence of virtual learning is viewed as a new form of innovation in teaching and learning which could support the teaching instructions.

\section{Technology-Based Learning Media for English Language Teaching}

In language learning, the existence of technology-based learning media is not a new matter. The learning media has been applied for decades and through time, many scholars have invented and investigated some technology-based learning media for supporting the English language learning and teaching activities based on students' learning style preference, such as video, audio podcast, virtual simulation through videoconferencing, and PowerPoint Presentations.

Video, which is served as an aid for the visual and auditory learning media preferences, has several benefits for the students. The video can serve real language expressions with cultural information of the target language (Bajrami \& Ismaili, 2016; Shahani \& Tahriri, 2015). Moreover, it shows also the specific facial expressions, gestures, and emotional attitudes shown by the speaker in the video (Bajrami \& Ismaili, 2016; Safarali \& Hamidi, 2012). In addition, the existence of video also raises students' positive attitude, motivation, and interest in the learning process (Nova, 2017). However, in some cases, the video just becomes the 
distraction of learning as the students only focus on the visual representation, not on the learning material shown on the video (Nova, 2017).

Meanwhile, the audio podcast is utilized to fulfill the need for auditory learning media preferences. With the concern on auditory learning media, the podcast can sharpen the student's listening comprehension (Agarid \& Nurzahra, 2018). It exposes the student's to a real language in use (Barjesteh \& Ghaseminia, 2019; Naidionova \& Ponomarenko, 2018) with clear and fluent speech with the right intonation (Agarid \& Nurzahra, 2018). Moreover, the online podcast can also prevent the student's boredom (Alshaikhi \& Madini, 2016) and raise their interest and motivation in learning the whole content attentively (Abdulrahman et al., 2018; Barjesteh \& Ghaseminia, 2019).

On the other hand, virtual simulation through videoconferencing could support the students with kinesthetic learning preferences. The online videoconferencing promotes an engaging real-time interaction in virtual learning (Vurdien, 2019) and could make the tasks more realistic for the students (Kristóf \& Tóth, 2020). With this effect, the virtual simulation can be easier to remember, memorize, and comprehend by the students (Kristóf \& Tóth, 2020). Affectedly, this kind of learning media creates more attractive virtual learning interaction and enhances the learning outcomes (Kristóf \& Tóth, 2020; Rop \& Bett, 2012). Otherwise, in many cases, bad signal connection, technical problems, and surrounding disturbance become obstacles in conducting videoconferencing (Nova, 2020). As videoconferencing takes real-time interaction between teacher and students, it may also possibly add more pressure and anxiety for students in learning (Archibald et al., 2019; Krouwel et al., 2019).

PowerPoint Presentations focus more on the visual learning style students. PowerPoint Presentation could combine the visual elements as a visual aid for the student in understanding the concept and the content of learning, such as pictures and words. The additional of pictures in PowerPoint Presentation are found to raise the student's attention on the slides (Tabatabaei \& Bandari, 2012). Moreover, the visual representations are remembered better in recalling the abstract concept (Mahmoudzadeh, 2014) and provide the student better insight into a complex learning topic concept (Tan, 2020). However, in certain cases, the PowerPoint Presentations are also difficult to grasp when it was not designed well and contained too many explanations and details (Gordani \& Khajavi, 2020).

From several investigations conducted, it could be concluded that each learning media can convey both benefits and drawbacks. It is necessary for an English lecturer to sort and select proper learning media to be utilized in virtual learning. Therefore, the selection of 
Volume 7, Number 01, June 2021

proper learning media plays a vital role to support the English teaching and learning activities and students' learning progress.

\section{METHOD}

\section{Respondents}

In conducting the study, this study took place in a vocational institute. There were 57 respondents participating in this study, with 33 male students and 24 female students. These respondents are students of hospitality management study program taking the Food and Beverage Service (F\&B Service) concentration. In F\&B Service concentration, these students learned English for a specific purpose with specialty learning topics, including telling restaurant's opening hours, telling prices on the menu, greeting, handling dinner reservation over telephone, seating the guest, taking orders, explaining the menu, handling complaints, and taking room service in a hotel. During the process of learning, these students were taught using an online platform, Google Classroom, and all learning materials and resources, including online video, online podcast, virtual simulation through videoconferencing, and PowerPoint Presentations, were sent through online directories. These learning media were then become the object evaluated in this study.

\section{Instruments}

During the investigation, this study employed two types of instruments, namely questionnaires and interview guides. Firstly, the questionnaire focuses on identifying the preference of technology-based learning media in virtual learning and also the reason for preferring the learning media. The questionnaire consisted of four sections, i.e. video, podcast, virtual simulation through videoconferencing, and PowerPoint Presentations. Each section consists of one close-ended question and one open-ended question. The close-ended question identifies the preferred technology-based learning media. Meanwhile, the open-ended question identifies the reasons for choosing or not choosing the learning media. These questions were constructed in the respondent's first language to make the respondents answer more accurately. Therefore, the questionnaire questions were constructed in Bahasa Indonesia since this study investigated Indonesian students. Then, the interview guide is employed to clarify the respondent's answer on the questionnaire which is unclear and/or ambiguous. Therefore, only several respondents were selected to be interviewed.

\section{Procedures}

The data collection was started after the respondents finishing their virtual learning for one semester. At the end of the semester, each respondent was asked to fill an online 
questionnaire which was distributed through Google Form. After receiving the respondent's responses, their answers were identified and some respondent's answers which are unclear and/or ambiguous were then highlighted. Then, to provide clearer insight, a short interview was also held via telephone with several respondents to confirm and to clarify several unclear statements mentioned in the questionnaire. The interview was conducted in Bahasa Indonesia to make the respondents answer more accurately. At the end of the interview, interview transcripts were made.

\section{Data analysis}

In this study, there were two types of data analysis employed; descriptive analysis and qualitative analysis. On descriptive analysis, the total responses to the close-ended questions in the questionnaire were analyzed by calculating and identifying the frequencies of each item, online video, online podcast, virtual simulation, and PowerPoint. Then, on the qualitative analysis, the responses to the open-ended questions in the questionnaire and interview result were analyzed through three phases; first, the data on both data collection were coded and separated into categories based on each learning media preference; second, the redundancies in the data separation were sorted out; and third, the results of the data analysis were displayed based on each learning media preference, i.e. online video, online podcast, virtual simulation, and PowerPoint. To gain deeper insight, the data were also displayed in form of narration and interpretation.

\section{FINDINGS AND DISCUSSION}

\section{Learning Media Evaluation in ESP Virtual Learning}

In response to the aim of the study that evaluates the learning media in ESP virtual learning, the students' attitude toward the learning media was firstly identified. Table 1 provides the distribution of the responses to the close-ended question for the preferred learning media in virtual learning.

Table 1. Preferred Learning Media in ESP Virtual Learning ( $=57)$

\begin{tabular}{|l|c|c|c|c|}
\hline Learning Media & Video & $\begin{array}{c}\text { Virtual Simulation through } \\
\text { Videoconferencing }\end{array}$ & Podcast & $\begin{array}{c}\text { PowerPoint } \\
\text { Presentations }\end{array}$ \\
\hline Students & $29(50.88 \%)$ & $17(29.82 \%)$ & $8(14.04 \%)$ & $3(5.25 \%)$ \\
\hline
\end{tabular}

From a total of 57 respondents, the video becomes the most preferred learning media in virtual learning. The students preferred to have the online video in their virtual learning rather than virtual simulation through videoconferencing, podcast, and PowerPoint Presentations. To provide clearer insight, each response on each learning media were analyzed to reveal 
further significant input for the study in considering proper learning media in ESP virtual learning.

\section{Video in ESP Virtual Learning}

Overall, it turned out that video becomes the most preferred learning media in virtual learning as it serves various benefits for the students. Consistent with the previous studies' findings (Bajrami \& Ismaili, 2016; Safarali \& Hamidi, 2012), many students mentioned that they could learn better with the visual and audio aids in the video. The students can directly observe the speaker's "mimic and facial expressions in a real situation" (S.20) occurring on the video. Moreover, as the speakers of the video are native speakers, the students also find the video more attractive. This finding also supports previous findings on the increasing number of positive attitudes among the students who learn with the help of video, including motivation and interest (Nova, 2017). In addition, the subtitle on the online video becomes an additional aid for learning, as one of the students expressed,

"I know that there is a feature on how to add subtitles into the video. If I cannot hear it clearly, I will turn on the subtitle and just read the text. It makes the learning easier for me and I can understand the learning material." (S.9)

With these benefits, video utilization has encouraged the students in learning and supports them in comprehending the language context and praxis. Nevertheless, there were some responses revealing the drawbacks of utilizing video in ESP virtual learning. Unlike the previous study's finding (Nova, 2017), the majority of the students complained more about their internet quota spending. This problem occurs since the students need to stream the video online, and as the length of video provided sometimes quite long, they are worried about the total internet quota that they need to charge in watching the video. Moreover, as the speakers on the video are native, some students mentioned the difficulties in catching the content of learning. In certain videos, they found the speakers "speak too fast and difficult to understand" (S.52) and they need to replay the video several times to understand the content on the video.

Considering the benefits and the drawbacks, the online video utilized in ESP virtual teaching needs to be taken into account. In line with the previous study's finding (MoralesSalas et al., 2020), considering the planning and instructional design plays a vital role in preparing virtual learning. Henceforth, the ESP teacher should sort and select the proper video content with a certain amount of time to make the students feel fewer burdens on their internet quota.

\section{Virtual Simulation through Videoconferencing in ESP Virtual Learning}


In this study, virtual simulation through videoconferencing becomes the second-most preferred learning media in virtual teaching. The selection of videoconferencing virtual simulation as students' preferred learning media is derived from the chances and realexperiences they get in applying the knowledge that they have learned into practice. The students had the willingness to try what they gained from learning and it was quite challenging for them. Furthermore, some students added that the learning praxis on virtual simulation through videoconferencing can improve their speaking ability. Specifically, the spontaneous responses in answering the guest's inquiries made them improve their content of speaking. During the videoconferencing, the lecturer and the students occur in a real-time situation (Vurdien, 2019), and thus, when the lecturer gave certain command or request, the students needed to respond it in only a certain amount of time. In addition, the students also revealed that, during the virtual simulation, their lecturer gave them feedback to improve their speaking ability, including fluency and pronunciation. The feedbacks given at the end of the virtual simulation also gave positive contribution on students' attitude toward videoconferencing utilization. Interestingly, some students even admitted that the virtual simulation made them study harder for preparing themselves to perform virtually. In other words, this learning media had motivated the students to learn and also raise their self-awareness on learning.

"During the simulation through videoconferencing, I study harder than before. I see it just like a real simulation for me. I faced the guests and, of course, I have to be ready to give the best response to them.” (S.19)

Although the virtual simulation through videoconferencing is viewed as a supportive learning media by the students, there were still some obstacles admitted by the students during the virtual learning. Pursuant to the previous study's finding (Nova, 2020), the majority of the students also experienced bad connection during conducting the virtual simulation. This bad connection affected their devices, including lagging screen and delayed voice in responding to the simulation task. Moreover, the real-time situation occurring in videoconferencing contributes to students' nervousness. One student even shared her experience in doing the virtual simulation through videoconferencing,

"To be honest, when I was doing the simulation, I was so nervous and anxious because I cannot speak English very well and my listening skill is not really good. I panicked since I can only hear some words. I needed a long time to think about the right response to what I hear, especially in making sentences in English. I am too nervous at that time." (S.20) 
To have regard to the students' responses to virtual simulation through videoconferencing, the advantages gained by the students are more crucial than the obstacles faced. It is undeniable that the real-time practice can raise students' anxieties (Archibald et al., 2019; Krouwel et al., 2019), however, as the major focus of ESP learning is to give them real professional learning context, providing real language praxis becomes the core element in ESP learning. In videoconferencing, the lecturer can design the task more realistic for the students (Kristóf \& Tóth, 2020). On the other hand, the students' anxieties and nervousness are profoundly identified as common obstacles faced by the students in experiencing a new situation (Archibald et al., 2019). Consequently, during the learning process, the students will get used to interact and communicate in English and their anxieties and nervousness will fade, albeit slowly. Henceforth, the ESP teacher should add more real-time language practice for students during the teaching and learning activities to help them improve their ability in using English as means of professional communication.

\section{Podcast in ESP Virtual Learning}

One of the learning media preferred in virtual learning by the students in this study is the podcast. Conclusively, the students viewed this learning media as a supportive tool for them in learning. In line with its main goal, the online podcast had helped and attracted the auditory preference students to learn better. The talk provided on the online podcast which took "light topic which is closely related to daily-conversation" (S.42) made them catch the content of learning easier. Regarding this, it can be taken into consideration that the typical exposures given in the online podcast is a daily talk and thus, it can expose the student's to a real language in use (Barjesteh \& Ghaseminia, 2019; Naidionova \& Ponomarenko, 2018) which supports their daily communication contents. Moreover, in line with prior studies (Abdulrahman et al., 2018; Barjesteh \& Ghaseminia, 2019), the students were also excited to listen to various accents provided in the online podcast and one of the students even explained,

"I am so curious about what the speakers said in the conversation. They are having different accents, like British, American, or Australian, maybe. I don't know. I just feel challenged to get into the talk and it is exciting." (S.45)

The positive responses given by the students seemed supporting the encouragement on the podcast as one learning media in virtual learning. Indeed, some students also admitted some ineffectivenesses of the media for their learning activities. In contra with the previous finding which argued the fluent speech becomes a positive attitude toward the podcast (Agarid \& Nurzahra, 2018), in this study, the fluency of the native speakers becomes an 
obstacle for the students in comprehending the listening content. The students admitted that some of the native speakers speak too fast to catch. Also, without having the listening transcripts, it made them work harder in listening to a single podcast; they admitted that they replayed the podcast several times before fully understand the learning content. On the other hand, some of the students also mentioned that some of the online podcast provided in virtual learning had moderate to low recording quality. Even, one of the students admitted that the low recording quality podcast hurt her,

"I am not sure whether I am having low listening ability or the podcast has a low quality recording. It is unclear and it hurts my ears." (S.27)

Scrutinizing the students' views on the online podcast, it can be inferred that the online podcast could affect the students' listening comprehension. Podcast, as its main purpose is not for learning materials, may become a burden for some students who do not get used to listening to native speakers. It will lead the students to gain better listening comprehension if the lecturer can provide a better quality of the podcast, not only on the technical qualities, but also the speaker qualities. Therefore, the lecture should be more selective in providing student-friendly podcast which can support the student's learning process.

\section{PowerPoint Presentations in ESP Virtual Learning}

PowerPoint Presentations become the least preferred learning media in this study. Only a few students saw it as an effective learning media; the students who selected this media were visual learners and they admitted that they learned better by viewing texts and images. As an aid for visual learners, the PowerPoint Presentations has provided visual representations for the abstract concept (Mahmoudzadeh, 2014). It was mentioned by one of the students who also added that the visualization provided in the PowerPoint Presentations eases the process of learning.

"The PowerPoint shown in virtual learning presents the summary of the learning content, so I can understand it well. Then, there are also some pictures in the PowerPoint slides, such as pictures of people doing some duties in the restaurant. It helps me to understand the concept and the procedure." (S.50)

However, the number of negative views on PowerPoint Presentations given by the students cannot resist the positive perception. The majority of the students admitted that they faced a high level of boredom during reading the learning material in PowerPoint presentations. In line with the previous study's finding on unwell-designed PowerPoint slides (Gordani \& Khajavi, 2020), in this study, the design of PowerPoint Presentation which only combines simple text and images also become the trigger of the boredom felt by the students 
as it looks monotonous and less attractive. Moreover, some students also mentioned the problem on the language praxis in reading PowerPoint Presentation.

"I think it is not effective enough because I just got the theory of English expressions without practicing it. Meanwhile, if I do some simulation, I can get experiences in using English. Then, I can also learn how to serve the guest politely, and if I make some mistakes, I can improve my performance right away". (S.17)

"If I only read the material, I cannot speak English well. I prefer if the lecturer can give practical video or do some in-hand simulation because I can listen to the proper way on how to speak and pronounce the English words correctly." (S.49)

Looking over the obstacles faced by the students in having PowerPoint Presentations in virtual learning, it can be seen that the mono-mode used in PowerPoint Presentations made it less supportive to students' learning progress; the students can only read the material, without enhancing other language skills, such as listening, speaking, and writing. Profoundly, it may help the visual learner gain better information processing during the learning progress, albeit conditionally; the PowerPoint Presentations should be provided with pictures or visualization (Mahmoudzadeh, 2014; Tabatabaei \& Bandari, 2012; Tan, 2020). Therefore, the lecturer should provide proper visualization in the PowerPoint Presentations to gain students' focus in learning attentively.

\section{E. CONCLUSION}

The existence of learning media in virtual learning had affected the students' learning progress. The utilization of technology-based learning media has been perceived positively by the students, albeit conditionally; certain learning media requires adjustments to meet the need of students' learning preferences and capabilities. Both positive and negative impacts had been experienced by the students during their virtual learning activities. Taking into consideration of the virtual learning media evaluation result, this research revealed that video becomes the most proper learning media to support the ESP virtual learning. The combination of visual and auditory modes in this learning media had gained positive perceptions from students. In contra, the PowerPoint Presentations become the least proper learning media in virtual learning since it only provides a single-mode (visual) with limited learning activities; the students focus on reading, without experiencing other skill-enhancement activities, such as listening, speaking, and writing. Therefore, the English lecturers who teach English for Specific Purposes are suggested to provide more video simulations on virtual learning platform to support the engagement of the teaching and learning activities. 


\section{REFERENCES}

Abdulrahman, T., Basalama, N., \& Widodo, M. R. (2018). The Impact of Podcasts on EFL Students' Listening Comprehension. International Journal of Language Education, 2(2), 23. https://doi.org/10.26858/ijole.v2i2.5878

Agarid, W. R., \& Nurzahra, M. (2018). Analyzing Podcast Application to Improve Listening Ability. PROJECT (Professional Journal of English Education), 1(3), 175-180. https://doi.org/10.22460/project.v1i3.p175-180

Al-Obaydi, L. (2019). Virtual Learning Environment as a Medium of Instruction in Higher Education. Proceedings of ISER 230th International Conference.

Alresheed, S., Leask, M., \& Raiker, A. (2015). Integrating Computer-Assisted Language Learning in Saudi schools: A Change Model. Turkish Online Journal of Educational Technology, 14(4), 69-77. https://doi.org/10.1007/978-3-319-33808-8_22

Alshaikhi, D., \& Madini, A. A. (2016). Attitude toward Enhancing Extensive Listening through Podcasts Supplementary Pack. English Language Teaching, 9(7), 32-47. https://doi.org/10.5539/elt.v9n7p32

Archibald, M. M., Ambagtsheer, R. C., Casey, M. G., \& Lawless, M. (2019). Using Zoom Videoconferencing for Qualitative Data Collection: Perceptions and Experiences of Researchers and Participants. International Journal of Qualitative Methods, 18, 1-8. https://doi.org/10.1177/1609406919874596

Bajrami, L., \& Ismaili, M. (2016). The Role of Video Materials in EFL Classrooms. Procedia Social and Behavioral Sciences, 232(2016), 502-506. https://doi.org/10.1016/j.sbspro.2016.10.068

Barjesteh, H., \& Ghaseminia, M. (2019). Effects of Pre-Listening Task Types on the Development of EFL Learners' Listening Comprehension Ability. International Journal of Listening, 1-15. https://doi.org/10.1080/10904018.2019.1654867

Baðöz, T. (2016). Pre-service EFL Teachers $\square$ Attitudes towards Language Learning through Social Media. Procedia - Social and Behavioral Sciences, 232(2016), 430-438. https://doi.org/10.1016/j.sbspro.2016.10.059

Bekteshi, E., \& Xhaferi, B. (2020). An Analysis of English for Specific Purposes among University Students. Educational Process: International Journal, 9(2), 90-102. https://doi.org/10.22521/edupij.2020.92.2

de Almeida Ferreira, A., dos Santos, N., da Costa, R. M. E. M., de A. Carneiro, F. A., \& Werneck, V. M. B. (2020). Evaluation Model of Virtual Learning Environments: A Pilot Study. International Journal for Innovation Education and Research, 8(8), 610-623. https://doi.org/10.31686/ijier.vol8.iss8.2569

Ezza, E.-S. Y., \& Bakry, S. A. (2015). Technology-Enhanced Instruction in a Saudi EFL Classroom. Arab World English Journal, 1(Special Issue on Call), 55-66. 
Gordani, Y., \& Khajavi, Y. (2020). The Impacts of Multi-modal PowerPoint Presentation on the EFL Students' Content Knowledge Attainment and Retention Over Time. Education and Information Technologies, 25(1), 403-417. https://doi.org/10.1007/s10639-019-09979-z

Ilmi, Z., Darma, D. C., \& Azis, M. (2020). Independence in Learning, Education Management, and Industry 4.0: Habitat Indonesia during COVID-19. Journal of Anthropology of Sport and Physical Education, 4(4), 63-66. https://doi.org/10.26773/jaspe.201010

Isisag, K. U. (2012). The Positive Effects of Integrating ICT in Foreign Language Teaching. ICT for Language Learning, 5, 1-4. http://conference.pixelonline.net/ICT4LL2012/common/download/Paper_pdf/235-IBT107-FP-IsisagICT2012.pdf

Jamal, A., \& Aldaifallah, H. M. (2020). Traditional Teaching or Virtual Learning: Better Option. International Journal of Psychosocial Rehabilitation, 24(6), 11267-11276. https://doi.org/10.37200/IJPR/V24I6/PR261109

Kofar, G. (2016). A Study of EFL Instructors' Perceptions of Blended Learning. Procedia Social and Behavioral Sciences, 232(April), 736-744. https://doi.org/10.1016/j.sbspro.2016.10.100

Kristóf, Z., \& Tóth, K. (2020). Developing and Examining a Virtual Learning Environment. Hungarian Educational Research Journal, 9(3), 511-526. https://doi.org/10.1556/063.9.2019.3.42

Krouwel, M., Jolly, K., \& Greenfield, S. (2019). Comparing Skype (Video Calling) and Inperson Qualitative Interview Modes in a Study of People with Irritable Bowel Syndrome: An Exploratory Comparative Analysis. BMC Medical Research Methodology, 19(1), 1-9. https://doi.org/10.1186/s12874-019-0867-9

Kumar, A., Anand, A., \& Kesri, V. (2020). Industry 4.0 to education 4.0 : An Indian Student Perspective. International Journal of Innovative Research in Technology, 6(12), 417-423.

Lopukhova, J., \& Makeeva, E. (2017). Creating Virtual Learning Environment: Shared Online Learning in University Education. International Journal for Cross-Disciplinary Subjects in Education, 8(2), 3046-3054. https://doi.org/10.20533/ijcdse.2042.6364.2017.0412

Mahmoudzadeh, S. (2014). The Effect of Using PowerPoint on Iranian EFL Learners' Knowledge of Abstract Vocabulary. Procedia - Social and Behavioral Sciences, 98(2014), 10771084. https://doi.org/10.1016/j.sbspro.2014.03.519

Meshkat, M., \& Mohammadpoor, R. (2015). Exploring the Role of CALL as a Cognitive Strategy in Rendering EFL Learners to Engage Learners in Reading Comprehension. International Journal of Language Learning and Applied Linguistics World, 9(1), 1-10.

Morales-Salas, R. E., Infante-Moro, J. C., \& Gallardo-Pérez, J. (2020). Evaluation of Virtual Learning Envirnments: A Management to Improve. International Journal of Educational Research and Innovation, 13, 126-142. 
Mustafa Kamal, N. N., Adnan, A. H. M., Yusof, A. A., Ahmad, M. K., \& Mohd Kamal, M. A. (2019). Immersive Interactive Educational Experiences: Adopting Education 5.0, Industry 4.0 Learning Technologies for Malaysian Universities. Proceedings: International Invention, Innovative \& Creative (InIIC) Conference, 2019, June, 190-196.

Naidionova, A. V., \& Ponomarenko, O. G. (2018). Use of Podcasting Technology to Develop Students' Listening Skills. Information Technologies and Learning Tools, 63(1), 177-185. https://doi.org/10.33407/itlt.v63i1.1962

Nova, M. (2017). Utilizing Video for Technology Integration Support in Indonesian EFL Classroom: Usages and Obstacles. Indonesian Journal of EFL and Linguistics, 2(1), 15-28. https://doi.org/10.21462/ijefll.v2i1.28

Nova, M. (2020). Videoconferencing for Speaking Assessment Medium: Alternative or Drawback. Journal of English Education and Applied Linguistics, 9(2), 111-128.

Rop, K. V, \& Bett, N. K. (2012). Video Conferencing and Its Application in Distance Learning. Annual Interdisciplinary Conference, The Catholic University of Eastern Africa, Nairobi Kenya., 1-9.

Safarali, S. K., \& Hamidi, H. (2012). The Impact of Videos Presenting Speakers' Gestures and Facial Clues on Iranian EFL Learners' Listening Comprehension. International Journal of Applied Linguistics and English Literature, 1(6), 106-114. https://doi.org/10.7575/ijalel.v.1n.6p.106

Salmani-nodoushan, M. A. (2020). English for Specific Purposes: Traditions, Trends, Directions. Studies in English Language and Education, 7(1), 247-268.

Shahani, S., \& Tahriri, A. (2015). The Impact of Silent and Freeze-Frame Viewing Techniques of Video Materials on the Intermediate EFL Learners' Listening Comprehension. SAGE Open, 5(2), 1-8. https://doi.org/10.1177/2158244015585999

Susilo, D. (2020). Industry 4.0: Is Indonesia Ready? Management Analysis Journal, 9(3), 262-270. https://doi.org/10.15294/maj.v9i3.39695

Tabatabaei, O., \& Bandari, M. M. (2012). Iranian EFL Learners' Attitudes towards the Use of Computer-Mediated PowerPoint Presentations. Theory and Practice in Language Studies, 2(2), 214-223. https://doi.org/10.4304/tpls.2.2.214-223

Tan, K. S. (2020). Power, Play and Pedagogy through the PowerPoint Performance-Lecture. International Journal of Management and Applied Research, 7(3), 382-394. https://doi.org/10.18646/2056.73.20-028

Vurdien, R. (2019). Videoconferencing: Developing Students' Communicative Competence. Journal of Foreign Language Education and Technology, 4(2), 269-298. 